\title{
Silicon Status and its Relationship with Major Physico-Chemical Properties of Vertisols of Northern Highlands of Ethiopia
}

\author{
Fassil Kebede
}

Department of LaRMEP, College of Dry Land Agriculture and Natural Resource Management, Mekelle University, P.O.Box-231, Mekelle, Ethiopia (fyimamu@gmail.com)

\begin{abstract}
Silicon is an essential mineral element for higher silicophile plant species and animals. Literature states that one of the most important functions of $\mathrm{Si}$ is the stimulation of plant's defense mechanism against abiotic and biotic stresses. In addition, Si fertilization has a more positive effect than liming on the chemical and physical properties of the soil. There are only a few studies in Ethiopia that present silicon status of some Ethiopian soils. Hence this study was initiated with the objective of understanding Si distribution in the soils of the northern highlands of Ethiopia. To this effect, 32 soil samples were collected from five agro ecological zones of Tigray. Si in all the samples was determined in the Laboratory of Ethiopian Geological Survey. This study revealed that Si contents ranged from 79.8 to $87.5 \mathrm{~g} \mathrm{Si} \mathrm{kg}^{-1}$ in the cultivated Vertisols of Adigudom, from 97.7 to $115.2 \mathrm{~g} \mathrm{Si} \mathrm{kg}^{-1}$ in Axum, from 113.7 to $117.2 \mathrm{~g} \mathrm{Si} \mathrm{kg}^{-1}$ in Maychew, from 130.0 to $133.9 \mathrm{~g} \mathrm{Si} \mathrm{kg}^{-1}$ in Shire and from 137.3 to $166.3 \mathrm{~g} \mathrm{Si} \mathrm{kg}^{-1}$ in Wukro. The highest concentration was hence found in Wukro where the sand content amounted to $50 \%$ whereas the lowest level was obtained from soils of Adigudom where the clay content exceeded $60 \%$. The Si contents in all the studied soils are lower than the documented ranges of 200 and $300 \mathrm{~g} \mathrm{Si} \mathrm{kg}^{-1}$. Significant correlation was found between silicon status and organic carbon $0.84 *(\mathrm{p}<0.05)$, silt $0.84 *(\mathrm{p}<0.05)$ and clay $0.84 *(\mathrm{p}<0.05)$. Finally, based on the enormous role of Si in plant physiology and agriculture, this study suggests commencing Si fertilization in these soils for an expected increase in crop productivity.
\end{abstract}

Keywords: Essential nutrient, Silica, Silicophile plant species and animals, Si Fertilization

\section{INTRODUCTION}

Since, crop production, is the major source of food for the population and hence it is the prime contributing sector to food security in Ethiopia. In addition, it plays a vital role in generating surplus capital to speed up the overall socio-economic conditions of the farmers. Ethiopia is believed to have a considerable land resource for agriculture. About 73.6 million hectares (66\%) of the country's land area is estimated to be potentially suitable for agricultural production (Fassil, 2002). It is generally accepted that this land resource can support a large population by providing enough food and other agricultural products required for the development of other sectors. However, the country has remained unable to feed its people for many years due to archaic agricultural practices and climate variability. 
The farming systems in Ethiopia can be classified into five major categories namely the highland mixed farming system, the lowland mixed agriculture, the pastoral system, shifting cultivation and commercial agriculture. The highland areas are inhabited by four-fifths of the population and also support about 70\% of the livestock population. According to Fassil (2002), crop production is estimated to contribute on average about $60 \%$, livestock accounts around $27 \%$ and forestry and other sub-sectors around $13 \%$ of the total agricultural value. Small-scale farmers who have been adopting low input and low output rainfed mixed farming with traditional technologies dominate the agriculture sector.

As the highland's population continues to grow rapidly, its agricultural land is becoming increasingly degraded. Farmers in the highlands are intensifying land use to meet food needs without proper management practices and cost effective inputs. The resulting depletion of nutrients from soils has caused crop production to stagnate or decline in the highlands. Unless a concerted effort is placed in confronting the problems of nutrient depletion, deteriorating agricultural productivity will seriously undermine the foundation of sustainable economic growth of the nation at large.

Silicon is the second most abundant element in the earth's crust constituting approximately 20 atomic \% of the lithosphere (Iler, 1979). In soil solutions, the prevailing form is monosilicic acid, $\mathrm{Si}(\mathrm{OH})_{4}$, with a solubility in water (at $25{ }^{\circ} \mathrm{C}$ ) of about $2 \mathrm{mM}$ (equivalent to $120 \mathrm{mg} \mathrm{SiO} 2$ per liter). On average, the concentrations in soil solutions are 30-40 $\mathrm{mg} \mathrm{SiO}_{2}$ per liter range between about 7 and $80 \mathrm{mg}$ ) with a tendency to lower concentrations at high $\mathrm{pH}(>7)$ and when large amounts of sesquioxides are present in soils and anion adsorption is dominant (Jones and Handreck, 1967).

Beginning in 1840, numerous laboratory, greenhouse and field experiments showed sustainable benefits of Si fertilization for rice (Oryza sativa L.), barley (Hordeum vulgare L.), wheat (Triticum vulgare Vil), maize (Zea mays L.), sugarcane (Saccharum officinarum), cucumber (Cucumus sativa L), tomato (Lycopersicon esculentum Mill), citrus (Citrus taitentis Risso) and other crops (Matichenkov and Calvert, 2002). Unfortunately, the present opinion about Si being an inert element is prevalent in plant physiology and agriculture despite the fact that $\mathrm{Si}$ is a biogeochemically active element and that $\mathrm{Si}$ fertilization has significant effects on crop production, soil fertility and environmental quality (Epstein, 1999; Matichenkov and Bocharnikova, 2000).

Higher plants differ characteristically in their capacity to take up silicon (Marschner, 1996). Depending on their $\mathrm{SiO}_{2}$ content (expressed as a percentage of shoot dry weight), they can be 
divided into three major groups: wetland Gramineae, such as wetland rice or horsetails (Equisetum), 10-15\%; dryland Gramineae, such as sugarcane and most of the cereal species, and a few dicotyledons, 1-3\%; and most dicotyledons, especially legumes, $<0.5 \%$ (Takahashi and Miyake, 1977).

Generally, silicon has more benefits such as the mobilization of soil phosphorus (Marschner, 1996), reduced water loss by cuticular transpiration, and increased resistance against lodging and pests, deserve more attention in the future in crops other than rice and sugarcane (Marschner, 1996). Ethiopia is a center of biodiversity where several landraces are under productivity. Reasons for poor crop production in Ethiopia are manifold. One of these may be nutrient depletion, elements like Si. Hence, the present study was carried out with the objective of auditing the current Si status in agriculturally important soils of the northern highlands of Ethiopia and suggest way forward with Si fertilization in crop production.

\section{MATERIALS AND METHODS}

\subsection{Soil sampling}

Soil samples were taken from five agroecological zones of Tigray, northern Ethiopia. Five profile pits were opened in representative sites of Adigudom, Axum, Maychew, Shire and Wukro. Soil samples were taken from 0-15, 15-30, 30-45, 45-60, 60-90, 90-140 and 140-160 cm depths. A total of 32 disturbed soil samples were collected. The disturbed soil samples were air dried and sieved to pass through $2 \mathrm{~mm}$ mesh prior to analysis.

\subsection{Soil analysis}

Organic carbon was analyzed according to Walkley and Black (1934) method, while total N was analyzed by Kjeldahl method (Bremner and Mulvaney, 1982) in the National Soil Research Laboratory in Addis Ababa. The silicon composition of the soil samples was determined following digestion with aqua regia and perchloric acid and finally was determined using Atomic Absorption Spectrophotometer. The silicon distribution in the soil samples was determined in Geochemistry Laboratory of the National Institute of Geological Survey in Addis Ababa. In addition, the silicon distribution was determined by multiplying a factor 0.47 with the $\mathrm{SiO}_{2}$ content that was determined in the Laboratory. Finally, the data were analyzed using Statistical Packages for Social Sciences (SPSS) 13 for windows. 


\section{RESULTS}

As presented in tables 1-5 the Si contents range in the cultivated Vertisols of Adigudom from 79.8 to $87.5 \mathrm{~g} \mathrm{Si} \mathrm{kg}^{-1}$, in Axum from 97.7 to $115.2 \mathrm{~g} \mathrm{Si} \mathrm{kg}^{-1}$, in Maychew from 113.7 to $117.2 \mathrm{~g}$ $\mathrm{Si} \mathrm{kg}^{-1}$, in Shire from 130.0 to $133.9 \mathrm{~g} \mathrm{Si} \mathrm{kg}^{-1}$ and finally in Wukro from 137.3 to $166.3 \mathrm{~g} \mathrm{Si} \mathrm{kg}^{-1}$. The highest concentration (i.e., 137.3 to $166.3 \mathrm{~g} \mathrm{Si} \mathrm{kg}^{-1}$ ) was found in Wukro where the sand content amounted to 50\% whereas the lowest level (81.4 to $95 \mathrm{~g} \mathrm{Si} \mathrm{kg}^{-1}$ ) was obtained from soils of Adigudom where the clay content exceeds $60 \%$.

The Pearson's correlation was used to find a correlation between silicon status and selected soil physical and chemical properties as given in table 6. Accordingly, significant correlation was found between silicon status and silt $-0.85 *(\mathrm{p}<0.05)$ and clay $0.85^{*}(\mathrm{p}<0.05)$ for Vertisols in Adigudom; between silicon and total nitrogen $0.77^{*}(\mathrm{p}<0.05)$ for Vertisols in Axum; between silicon and sand -0.88* $(\mathrm{p}<0.05)$ (Isn't sand positively correlated with Si under normal circumstances-check your results!) and clay $-0.88^{*}(\mathrm{p}<0.05)$ for the Vertisols in Shire and between silicon and clay $-0.85(\mathrm{p}<0.05)$. The test showed, in most cases, that there is nonsignificant correlation between $\mathrm{Si}$ content and $\mathrm{pH}$ and soil organic carbon (Table 6). These properties in turn determine silicon's effect on soil fertility and plants.

Table 1. Physical and chemical properties of Vertisols of Adigudom.

\begin{tabular}{|l|c|c|c|c|c|c|c|}
\hline $\begin{array}{c}\text { Depth } \\
(\mathbf{c m})\end{array}$ & $\boldsymbol{p H}$ & $\begin{array}{c}\text { Sand } \\
(\%)\end{array}$ & $\begin{array}{c}\text { Silt } \\
\mathbf{( \% )}\end{array}$ & $\begin{array}{c}\text { Clay } \\
(\%)\end{array}$ & $\begin{array}{c}\boldsymbol{T N} \\
(\%)\end{array}$ & $\begin{array}{c}\text { OC } \\
(\%)\end{array}$ & $\begin{array}{c}\text { Si } \\
\left(\boldsymbol{g} \mathbf{~ k g}^{-1} \text { soils }\right)\end{array}$ \\
\hline $0-15$ & 8.4 & 16 & 22 & 62 & 0.116 & 1.5 & 87.1 \\
\hline $15-30$ & 8.4 & 18 & 22 & 60 & 0.106 & 1.4 & 87.4 \\
\hline $30-45$ & 8.3 & 14 & 23 & 63 & 0.084 & 1.0 & 87.5 \\
\hline $45-60$ & 8.4 & 16 & 20 & 64 & 0.082 & 1.4 & 84.6 \\
\hline $60-90$ & 8.6 & 12 & 26 & 62 & 0.081 & 1.4 & 82.3 \\
\hline $90-140$ & 8.0 & 18 & 64 & 22 & 0.095 & 1.8 & 74.8 \\
\hline $140-160$ & 8.4 & 14 & 28 & 54 & 0.070 & 1.0 & 79.1 \\
\hline
\end{tabular}


Table 2. Physical and chemical properties of Vertisols of Axum.

\begin{tabular}{|l|c|c|c|c|c|c|c|}
\hline \multicolumn{1}{|c|}{$\begin{array}{c}\text { Depth } \\
(\mathbf{c m})\end{array}$} & $\boldsymbol{p H}$ & $\begin{array}{c}\text { Sand } \\
(\%)\end{array}$ & $\begin{array}{c}\text { Silt } \\
(\%)\end{array}$ & $\begin{array}{c}\text { Clay } \\
(\%)\end{array}$ & $\begin{array}{c}\text { TN } \\
(\%)\end{array}$ & $\begin{array}{c}\text { OC } \\
(\%)\end{array}$ & $\begin{array}{c}\text { Si } \\
\left(\boldsymbol{g} \mathbf{~ k g}^{-1} \text { soils }\right)\end{array}$ \\
\hline $0-15$ & 8.4 & 14 & 34 & 52 & 0.148 & 1.2 & 111.3 \\
\hline $15-30$ & 8.5 & 12 & 30 & 58 & 0.127 & 1.1 & 114.1 \\
\hline $30-45$ & 9.0 & 12 & 24 & 64 & 0.120 & 1.0 & 114.8 \\
\hline $45-60$ & 9.0 & 12 & 26 & 62 & 0.111 & 0.9 & 112.7 \\
\hline $60-90$ & 9.1 & 16 & 24 & 60 & 0.116 & 0.8 & 115.2 \\
\hline $90-140$ & 8.7 & 16 & 28 & 56 & 0.062 & 0.8 & 109.1 \\
\hline $140-160$ & 8.3 & 18 & 26 & 56 & 0.051 & 0.6 & 97.7 \\
\hline
\end{tabular}

Table 3. Physical and chemical properties of Vertisols of Maychew.

\begin{tabular}{|c|c|c|c|c|c|c|c|}
\hline $\begin{array}{c}\text { Depth } \\
(\mathbf{c m})\end{array}$ & $\mathbf{p H}$ & $\begin{array}{c}\text { Sand } \\
\mathbf{( \% )}\end{array}$ & $\begin{array}{c}\text { Silt } \\
(\%)\end{array}$ & $\begin{array}{c}\text { Clay } \\
\mathbf{( \% )}\end{array}$ & $\begin{array}{c}\mathbf{T N} \\
(\%)\end{array}$ & $\begin{array}{c}\text { OC } \\
(\%)\end{array}$ & $\begin{array}{c}\text { Si } \\
\left(\mathbf{g} \mathbf{~ k g}^{-1} \text { soils }\right)\end{array}$ \\
\hline $0-15$ & 7.4 & 20 & 20 & 60 & 0.106 & 0.7 & 113.7 \\
\hline $15-30$ & 7.8 & 20 & 32 & 60 & 0.069 & 0.6 & 113.8 \\
\hline $30-45$ & 8.0 & 20 & 32 & 48 & 0.067 & 0.5 & 114.7 \\
\hline $45-60$ & 8.1 & 18 & 30 & 48 & 0.041 & 0.3 & 114.5 \\
\hline $60-90$ & 8.4 & 14 & 30 & 52 & 0.040 & 0.3 & 114.8 \\
\hline $90-140$ & 6.4 & 14 & 30 & 56 & 0.038 & 0.3 & 117.2 \\
\hline
\end{tabular}

Table 4. Physical and chemical properties of Vertisols of Shire.

\begin{tabular}{|l|c|c|c|c|c|c|c|}
\hline $\begin{array}{c}\text { Depth } \\
(\mathbf{c m})\end{array}$ & $\boldsymbol{p H}$ & $\begin{array}{c}\text { Sand } \\
(\%)\end{array}$ & $\begin{array}{c}\text { Silt } \\
(\%)\end{array}$ & $\begin{array}{c}\text { Clay } \\
(\%)\end{array}$ & $\begin{array}{c}\mathbf{T N} \\
(\%)\end{array}$ & $\begin{array}{c}\text { OC } \\
(\%)\end{array}$ & $\begin{array}{c}\text { Si } \\
\left(\mathbf{g} \mathbf{~ k g}^{-1} \text { soils }\right)\end{array}$ \\
\hline $0-15$ & 6.9 & 10 & 32 & 58 & 0.057 & 0.7 & 133.1 \\
\hline $15-45$ & 7.0 & 10 & 32 & 58 & 0.069 & 0.6 & 133.9 \\
\hline $45-60$ & 7.3 & 12 & 28 & 60 & 0.073 & 0.6 & 130.9 \\
\hline $60-90$ & 7.5 & 12 & 28 & 60 & 0.050 & 0.5 & 131.9 \\
\hline $90-140$ & 7.5 & 12 & 28 & 60 & 0.043 & 0.7 & 130.0 \\
\hline
\end{tabular}


Table 5. Physical and chemical properties of Vertisols of Wukro.

\begin{tabular}{|l|c|c|c|c|c|c|c|}
\hline $\begin{array}{c}\text { Depth } \\
(\mathbf{c m})\end{array}$ & $\boldsymbol{p H}$ & $\begin{array}{c}\text { Sand } \\
\mathbf{( \% )}\end{array}$ & $\begin{array}{c}\text { Silt } \\
(\%)\end{array}$ & $\begin{array}{c}\text { Clay } \\
(\%)\end{array}$ & $\begin{array}{c}\text { TN } \\
(\%)\end{array}$ & $\begin{array}{c}\text { OC } \\
(\%)\end{array}$ & $\begin{array}{c}\text { Si } \\
\left(\mathbf{g} \mathbf{k g}^{-1} \text { soils }\right)\end{array}$ \\
\hline $0-15$ & 8.2 & 50 & 20 & 30 & 0.078 & 1.0 & 166.3 \\
\hline $15-30$ & 8.2 & 40 & 20 & 40 & 0.088 & 1.4 & 153.8 \\
\hline $30-45$ & 8.5 & 33 & 23 & 44 & 0.090 & 1.1 & 141.1 \\
\hline $45-60$ & 8.3 & 33 & 23 & 44 & 0.092 & 1.1 & 137.3 \\
\hline $60-90$ & 8.5 & 31 & 20 & 49 & 0.060 & 1.0 & 141.3 \\
\hline $90-140$ & 8.7 & 13 & 38 & 49 & 0.066 & 1.0 & 144.9 \\
\hline $140-160$ & 8.5 & 36 & 17 & 47 & 0.063 & 0.9 & 146.5 \\
\hline
\end{tabular}

Table 6. Correlation between silicon and major soil physical and chemical properties in Vertisols of Tigray.

\begin{tabular}{|l|l|l|l|l|l|}
\hline Soil properties & Adigudom & Axum & Maychew & Shire & Wukro \\
\hline $\mathrm{pH}$ & 0.53 & 0.67 & -0.67 & -0.81 & -0.56 \\
\hline Sand & -0.08 & -0.73 & -0.75 & $-0.88\left(^{*}\right)$ & 0.65 \\
\hline Silt & $-0.85\left(^{*}\right)$ & -0.01 & 0.30 & $0.88\left(^{*}\right)$ & -0.22 \\
\hline Clay & $0.85\left(^{*}\right)$ & 0.45 & -0.16 & $-0.88\left(^{*}\right)$ & $-0.85\left(^{*}\right)$ \\
\hline Total N & 0.39 & $0.77(*)$ & -0.65 & 0.43 & 0.00 \\
\hline Soil organic C & -0.15 & 0.67 & -0.73 & 0.70 & -0.05 \\
\hline
\end{tabular}

* Correlation is significant at the 0.05 level (2-tailed).

\section{DISCUSSION}

The Si values in the Vertisols of Tigray are less than from the previously reported Si content for clay soils. As silicon is the most abundant element in the earth's crust after oxygen, it ranges from 200 to $300 \mathrm{~g} \mathrm{Si} \mathrm{kg}^{-1}$ in clay soils and 450 to $480 \mathrm{~g} \mathrm{Si} \mathrm{kg}^{-1}$ in sandy soils (Kovda, 1973; Matichenkov and Calvert, 2002). Although the Si contents in Vertisols of Debre Zeit and Sheno in the Central Highlands of Ethiopia fall within this range (Fisseha Itanna, 1992), the clay soils in Tigray Region have much lower Si. The comparatively lower values for Si in these soils can be justified due to; first, severe and frequent soil erosion and sediment transportation in the study areas. Secondly, usually plants absorb Si more than other elements (Savant et al., 1997); hence, 
much Si should be replaced to ensure sustainable yields. Thirdly, the nature of parent materials in the study areas could be the cause for the lowered Si levels in these soils. Virtually, the main portions of soil Si-rich compounds are represented by quartz or crystalline silicates, which are confirmed in this current studies where the highest Si content was found in sand dominated soils. The physically and chemically active Si substances in the soils are represented by soluble and weakly adsorbed monosilicic acids, polysilicic acids, and organosilicon compounds (Matichenkov and Ammosova, 1996). These forms are interchangeable with each other as well as with other crystalline minerals and living organisms (soil microorganisms and plants). Monosilicic acid is the center of these interactions and transformations. Monosilicic acids are the product of Si-rich mineral dissolution (Lindsay, 1979). Plants and microorganisms can absorb only monosilicic acid (Yoshida, 1975). Polysilicic acid has a significant effect on soil texture, water holding capacity, adsorption capacity, and soil erosion stability (Matichenkov et al., 1995). The study concludes that quantifying monosilicic and polysilicic acid contents and conduct applied research so as to elaborate optimum Si rate and best time and methods of its application are imperative. It is also advisable to consider additional Si extractants to those used in this study. Plant uptake studies may also be useful to justify whether it contributes to the low levels of Si in Tigray Region.

\section{ACKNOWLEDGEMENT}

The researcher duly acknowledges the Ethiopian Institute of Agricultural Research for funding the project and technicians of the Department of Land Resource Management and Environmental Protection of Mekelle University for sample collection.

\section{REFERENCES}

Bremner, J.M. \& Mulvaney, C.S. 1982. Total Nitrogen. In: A.L. Page, R.H. Miller and D.R. Keeney (eds.), Methods of soil analysis, Part 2 - Chemical and microbiological properties. Agronomy, Am. Soc. of Agron., Madison, Wisconsin, 9 (2): 595-624.

Epstein, E. 1999. The discovery of the essential elements. In: S.D. Kung and S.F. Yang (eds.), Discoveries in plant biology, Volume 3, World Scientific Publishing, Singapore.

Fassil Kebede. 2002. Analysis of yield gap for wheat cultivation in the highlands of north Ethiopia. Ph.D thesis, Gent University, Belgium (unpubl.). 
Fisseha Itanna. 1992. Micro- and macronutrient distributions in Ethiopian Vertisol landscapes. Ph.D Thesis, Hohenheimer Bodenkundliche Hefte (2), University of Hohenheim, Stuttgart, Germany (unpubl.).

Iler, R. K. 1979. The chemistry of silica - solubility, polymerization, colloid and surface properties, and biochemistry. Wiley \& Sons, New York, pp. 866.

Jones, L.H.P. \& Handreck, K.A. 1967. Silica in soils, plants and animals. Adv. Agron., 19: 107149.

Kovda, V.A. 1973. The bases of learning about soils. Volume 2, Nauka, Moscow.

Lindsay, W.L.1979. Chemical Equilibria in Soil. John Wiley \& Sons, New York.

Marschner, H. 1996. Mineral Nutrition of Higher Plants. Academic Press INC San Diego, CA 92101.

Matichenkov, V.V., Pinsky, D.L. \& Bocharnikova, E.A. 1995. Influence of mechanical compaction of soils on the state and form of available silicon. Eurasian Soil Science, 27 (12):58-67.

Matichenkov, V.V. \& Ammosova. 1996. Effect of amorphous silica on soil properties of a sodpodzolic soil. Eurasian Soil Science, 28 (10):87-99.

Matichenkov, V.V. \& Bocharnikova, E.A. 2000. Comparison study of soil silicon status in sandy soils of south Florida. Proc. Soil Crop Sci., Florida, 59:132-137.

Matichenkov, V.V. \& Calvert, D.V. 2002. Silicon as beneficial element for sugarcane. J. American Society of Sugarcane Technologists, Volume 22.

Savant, N.K., Korndorfer, G.H. \& Datnoff, L.E. 1997. Silicon management and sustainable rice production. Advances in Agronomy, 58:151-199.

Takahashi \& Miyake, 1977. Silica and plant growth. Proc. Int. Seminar, Soil Environ. Fert. Management Intensive Agriculture, 603-611.

Walkley, A. \& Black, I.A. 1934. An examination of the Degtijareff method for determining soil organic matter and proposed chromic and titration method. Soil Science, 37:29-38.

Yoshida, S. 1975. The physiology of silicon in rice. Bulletin No.25, Food FERT. Tech. Centre, Taipei, Taiwan. 